\title{
STRUCTURAL ANALYSIS OF DIFFERENTIATED SCHISTS AND GNEISSES IN THE TAALINTEHDAS AREA, KEMIÖ ISLAND, SOUTHWEST FINLAND
}

\author{
PETER N. W. VERHOEF and EUGENE J. L. DIETVORST
}

\begin{abstract}
VERHOEF, P. N. W and DIETVORST, E. J. L., 1980: Structural analysis of differentiated schists and gneisses in the Taalintehdas area, Kemiö Island, southwest Finland. Bull. Geol. Soc. Finland 52-2, $147-164$.
\end{abstract}

Structural analysis of the Svecokarelic supracrustal schists and gneisses from around Taalintehdas, SW Kemiö Island, SW Finland, has been carried out and a preliminary interpretation is given of the regional structure of Kemiö Island in terms of the fold generations determined in the Taalintehdas area. The first generation of isoclinal folds is established by means of overprinting relationships in the schists. The second generation is marked by tight to isoclinal folds which further transposed earlier layering and foliation. The dominant N70E trending transposition foliation ( $\left.\mathrm{S}_{2}\right)$ is openly folded by third generation folds with a N35E trending axial plane crenulation cleavage. Parasitic folds abound in the core of large scale $\mathrm{F}_{3}$ folds; $\mathrm{S}_{3}$ transposition foliation is developed locally. This distinctive tectonic layering is folded by $\mathrm{F}_{4}$ chevron folds with locally developed EW axial plane foliation. The $\mathrm{F}_{4}$ folds are restricted to regions where earlier foliations were oriented NS after the third folding phase. The rocks were metamorphosed under amphibolite facies conditions resulting in the blastesis of sillimanite, andalusite, cordierite and garnet in the schists. The relationship between deformation and metamorphism is discussed.

P. N. W. Verhoef 1 and E. J. L. Dietvorst, Institute of Earth Sciences, Free University; De Boelelaan 1085, 1081 HV Amsterdam, Netherlands.

\section{Introduction}

This paper deals with a structural analysis of a small area of the Svecokarelic KemiöOrijärvi belt in SW Finland, previously mapped and extensively described by Eskola (1914). The work is part of a larger programme on the evolution of the Kemiö-Ori-

1 Present address: Department of Structural and Applied Geology, Institute of Earth Sciences, P.o. Box 80.021, 3508 TA Utrecht, Netherlands

2 This investigation is part of a petrological project that has been carried out in the Kemiö area since 1974 by staff members and students of the Free University of Amsterdam under the direction of Dr. László Westra. järvi belt. ${ }^{2}$ Detailed structural analysis of the area around Taalintehdas (Dalsbruk) was undertaken to unravel the complex geological history of this belt. The rocks described are supracrustal mica schists and gneisses with well preserved mesoscopic structures. Being the oldest rock type so far recognized in the Kemiö-Orijärvi belt, the supracrustal rocks are a potential source of the most complete information on the deformation history. First the geological setting, petrography and structures of the schists and gneisses are described, then the microstructures and the relative ages of metamorphic mineral growth are discussed. 
Finally an attempt is made to synthesize the structure and history of the Taalintehdas area and Kemiö Island.

\section{Geological setting}

\section{Kemiö-Orijärvi Belt}

The Kemiö-Orijärvi belt is part of the Svecokarelic orogen of Early Proterozoic age. The evolution of the belt has been described in terms of geosynclinal sedimentation of supracrustal rocks (leptites); deformation with concurrent intrusion of »synkinematic» rock suites (the »oligoclase granites» of Eskola (1914), later termed »trondhjemites» and "granodiorites» by Simonen (1960)) including minor gabbroic and peridotitic rocks; continuing deformation and finally emplacement of migmatizing »late kinematic» microcline granites in the closing stages of the orogeny (Simonen, 1971).

\section{Kemiö Island}

On Kemiö Island (Fig. 1) the central part of the belt consists of a series of fine-grained supracrustal gneisses with intercalations of amphibolites, and minor amounts of schists, marbles and associated calc-silicate rocks. Elongated bodies of amphibole gneiss, amphibolite and cordierite-anthophyllite rock are widespread, and some of them provide evidence of volcanic origin (pillow lavas, agglomerates). Their mineral parageneses are characteristic of amphibolite facies metamorphism.

The external zones of the belt contain synkinematic infracrustals which are mostly granitic of granodioritic gneisses in the south and tonalitic gneisses in the north. The latter form a series of gabbro-tonalite in relative order of intrusion, with cross-cutting minor granodioritic material. Deformation of supra- and infracrustal rocks was intense and resulted in a generally steep dipping east-west foliation with transposition of layering and intercalated rock bodies parallel to this foliation. Foliations deviating from the general EW trend occur west and north of Taalintehdas and by the dome-shaped structure encirling the islet of Bergö. Large batholiths of non-gneissose late-kinematic microcline granite are encountered north and south of the belt.

\section{Taalintehdas area}

The southern part of the area around Taalintehdas is composed of schists separated by a sharp lithological boundary from the Masugnsträsk gneisses in the north (Fig. 2). Intricately foldel quartz veinlets are common in both schists and gneisses. Pegmatite and aplite veins and dykes also occur. These veins and dykes are boudinaged and folded, but some cross-cut older structures and are apparently younger. Pegmatites are more abundant in the schists. The zonal pegmatites consist of microcline, plagioclase, biotite, muscovite, quartz, and occasionally beryl.

The Taalintehdas schists are layered (10-30 cm scale), dark grey or brownish schists with gneissic intercalations up to $20 \mathrm{~cm}$ thick. The schists are fine grained $(0.1-0.3 \mathrm{~mm})$ and consist essentially of quartz, muscovite, biotite and oligoclase. Cordierite porphyroblasts (or pseudomorphs) and fibrolitic sillimanite are common and occasionally andalusite porphyroblasts are observed. Garnet porphyroblasts are restricted to a layer of biotite schist which occurs in the sequence.

The Masugnsträsk gneisses are dominantly fine-grained (ca. $0.1 \mathrm{~mm}$ ) quartz-feldspar gneisses with isolated, intricately folded patches of medium-grained (ca. $1 \mathrm{~mm}$ ) biotite schist and amphibolite intercalations up to 10 $\mathrm{cm}$ thick. The constituent minerals of the gneisses are quartz, microcline, oligoclase, 


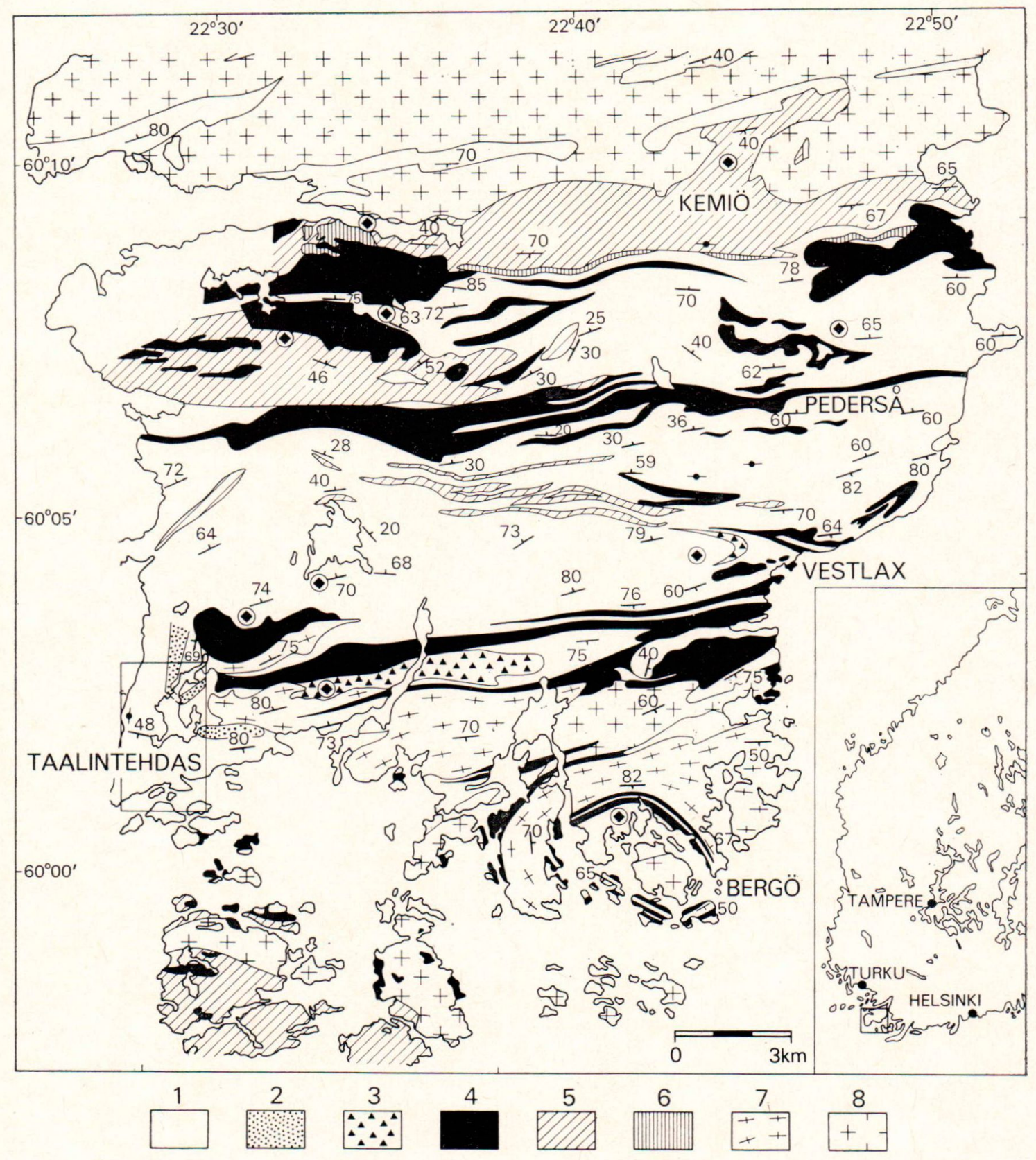

Fig. 1. Simplified geological map of Kemiö Island: 1. metapelite and metapsammite; 2. quartzite; 3. pillow basalt and pyroclastics; 4. metagabbro and amphibolite; 5 . tonalitic gneiss and amphibole gneiss; 6. granodioritic gneiss and augengneiss; 7. granitic and granodioritic gneiss; 8 . microcline granite. Locations where structural analysis has been carried out are indicated by a black square.

biotite and muscovite. Garnet porphyroblasts are encountered in the biotite schists. The essential constituents of the amphibolite are hornblende, quartz, and sericitized plagioclase. Quartzite bodies, $250 \mathrm{~m}$ wide in outcrop, are included in the gneiss series. 


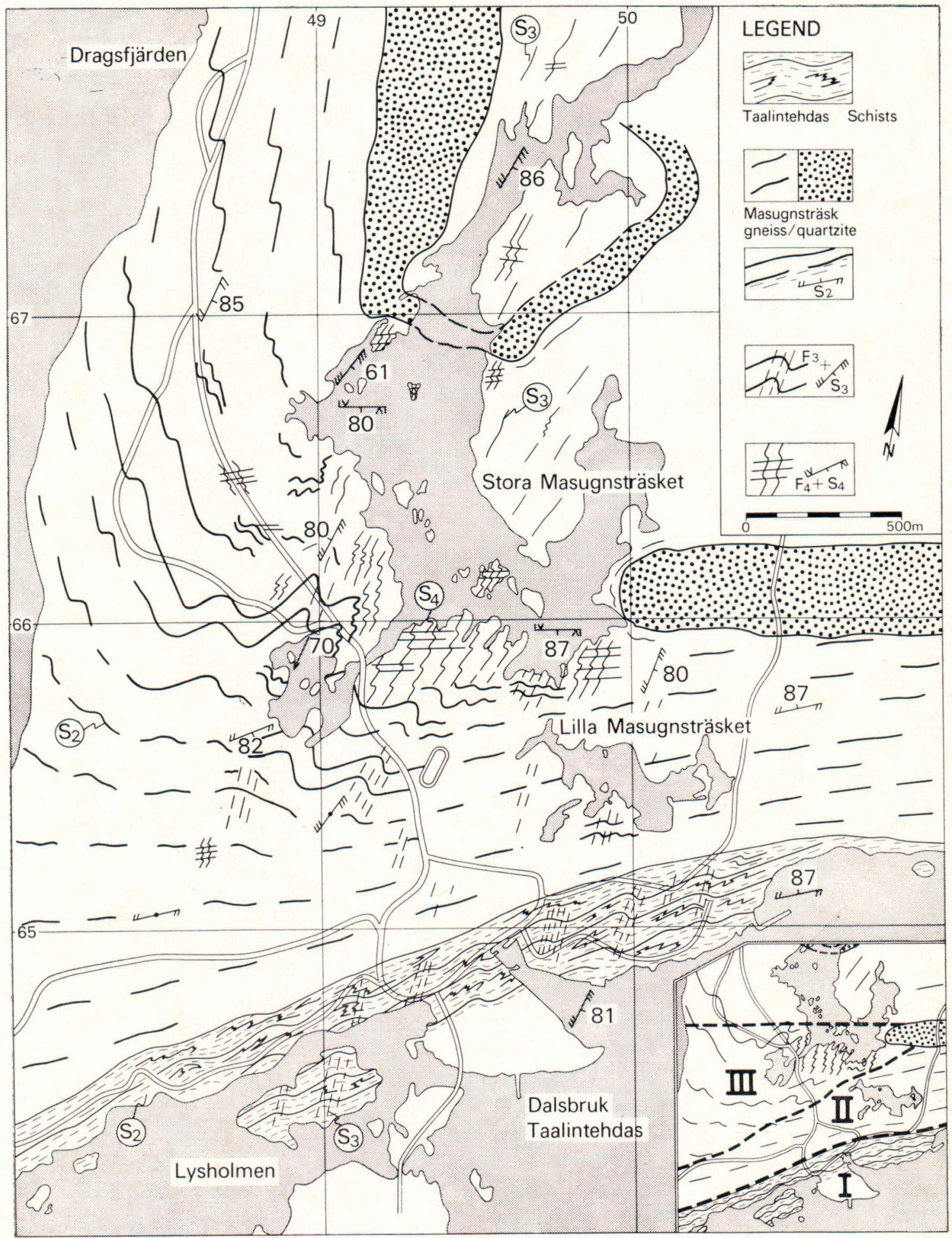




\section{Structural analysis ${ }^{1}$}

With the aid of overprinting relationships, four fold generations can be distinguished in the supracrustal rocks around Taalintehdas. In addition to local analysis of refolded fold structures, form surface maps were prepared to gain insight into the geometrical relationships of the mesoscopic structures and to facilitate macroscopic interpretation (Hobbs et al., 1976). The area can be divided into three structural domains, distinguished on the basis of the dominating structural elements (Figs. 2 and 10).

\section{Taalintehdas schists}

The most prominent structural feature in the Taalintehdas schists is a pervasive N70E striking foliation defined by transposed layering and preferred orientation of micas and other minerals. Intrafolial folds associated with this foliation are isoclinal and are refolded by tight to isoclinal asymmetric $\mathrm{F}_{2}$ folds related to the pervasive schistosity, $\mathrm{S}_{2}$ (Fig. 3). Locally this transposition foliation has been deformed into open folds, and a new crenulation cleavage $\left(\mathrm{S}_{3}\right)$ with a N35E strike is present. The form surface map of an exposure in the schists shows an example of the mesoscopic structures observed (Fig. 4). Since fold axes, mineral lineations and foliations are subvertical (Fig. 10), the map is a reasonable approximation to a structural profile (Figs. 2 and 4).

Fig. 2. Interpretation of macroscopic structure of the Taalintehdas area. The large scale fold in the centre of the map is an $\mathrm{F}_{3}$ fold. Inset shows structural domains: I. Taalintehdas schists; II. Masungnsträsk gneisses characterized by predominance of $\mathrm{S}_{2}$ transposition foliation; III. Masungnsträsk gneisses with dominant $F_{3}$ parasitic folding and widespread occurrence of $\mathrm{F}_{4}$ structures.
$\mathrm{F}_{1}$ structures

The existence of $F_{1}$ folds is evident only where they are overprinted by $\mathrm{F}_{2}$ folds. Where such overprinting structures are absent it is impossible to distinquish $\mathrm{F}_{1}$ and $\mathrm{F}_{2}$ folds, since they have the same orientation and essentially the same style. $\mathrm{F}_{1}$ folds, however, are generally somewhat tighter, but this might be true only where they are refolded. The amplitude of $F_{1}$ folds rarely exceeds 50 $\mathrm{cm}$ (Figs. 3 and 5). Because of intense later deformation it has not been possible to study the relationship of $\mathbf{S}_{1}$ and $\mathbf{S}_{0}$ (presumed initial layering). The original appearance of $\mathrm{S}_{1}$ foliation is obscured by $\mathrm{F}_{2}$ structures. $\mathrm{S}_{1}$ can be recognized as a regular schistosity defined by preferred orientation of mica or as a crenulation cleavage in the hinges of some open $\mathrm{F}_{2}$ folds. The foliation folded by $F_{2}$ commonly constitutes irregular differentiated layering (quartz rich / mica rich). Numbers of the quartz veinlets which invaded the schists show $\mathrm{F}_{1}$ folding. These observations suggest that $\mathrm{F}_{1}$ deformation may have been associated with metamorphic differentiation.

\section{$\mathrm{F}_{2}$ structures}

Tight or isoclinal $\mathrm{F}_{2}$ folds ( $\mathrm{cm}-\mathrm{m}$ scale) with predominantly dextral vergence are widespread in the schists. Their hinges are sharp or rounded. The layering folded by $\mathrm{F}_{2}$ folds is discontinuous, and rootless intrafolial

1 Terminology of axial plane foliations in this paper is in accordance with that used by Hobbs et al. (1976), Chapter 5. Differentiated crenulation cleavage is similar to the layered crenulation cleavage used by Marlow and Etheridge (1977). The terms $S_{1}, S_{2}, S_{3}, \ldots$ refer to the axial plane schistosity of fold generations $F_{1}, F_{2}, F_{3}, \ldots$ These terms have no genetic implication. Thus, earlier foliations transposed parallel to the $\mathrm{S}_{2}$ axial plane schistosity are also referred to as $\mathrm{S}_{2}$, and not as $\mathrm{S}_{2+1}$ or $\mathrm{S}_{2+1+0}$, since it is generally impossible in the field to distinguish between newly developed axial plane cleavages and older foliations transposed parallel to them. 

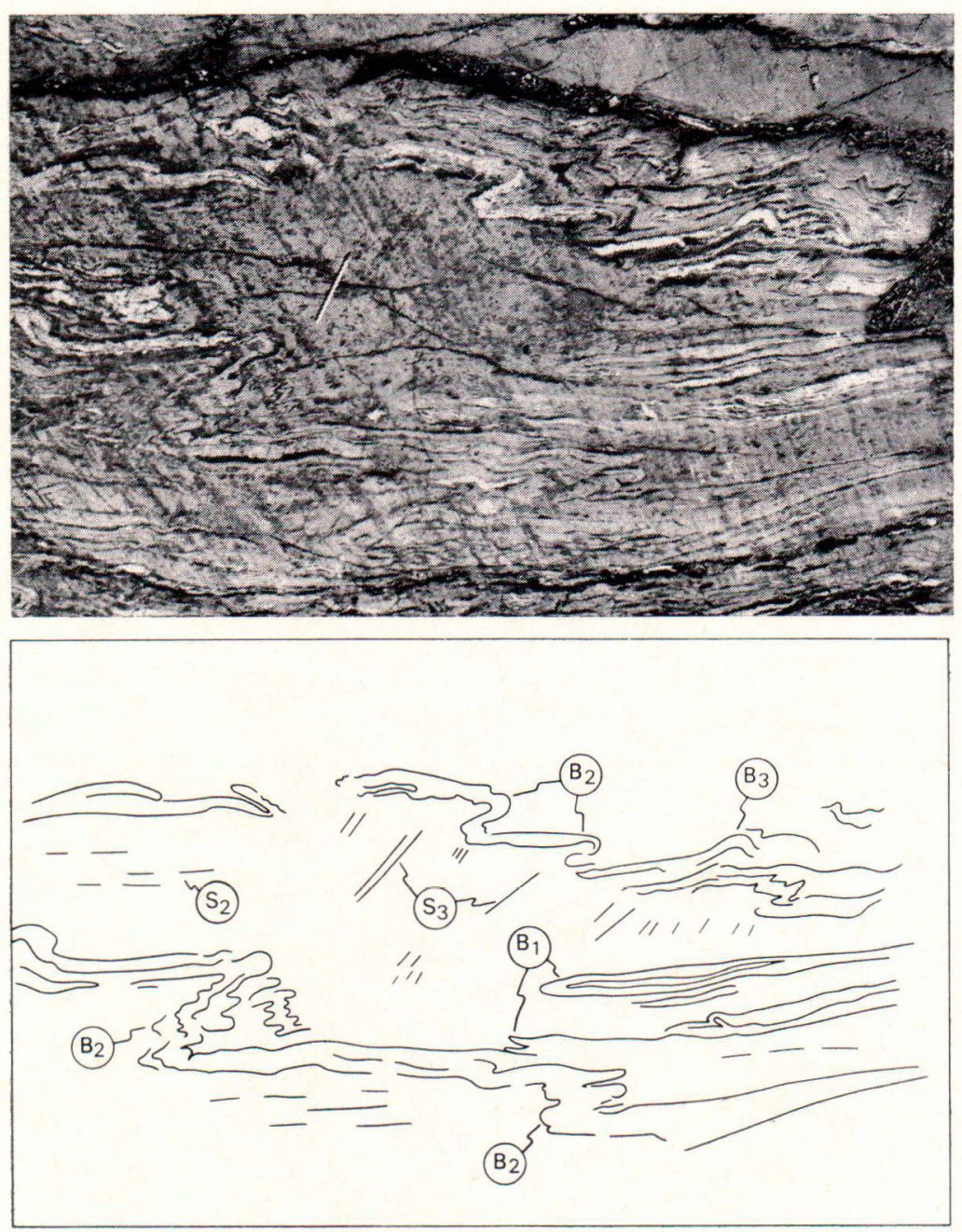

Fig. 3. Overprinting relationships in quartz-mica schist. Rootless, isoclinal fold is interpreted as an $F_{1}$ structure because of the vergence of surrounding $\mathrm{F}_{2}$ folds. S3 crenulation (parallel to the pencil) trends NNE. Location 65.23-49.98 (see grid in Fig. 2). folds are common. Layering is seen on all scales to be transposed parallel to the $\mathrm{S}_{2}$ axial plane schistosity. A penetrative steeply plunging mineral lineation $\left(\mathrm{L}_{2}\right)$ is approximately parallel to $B_{2}$ fold axes. The nature of the microfabric is strongly dependent on the relative amounts of quartz and mica. The quartz-rich material exhibits regular mica schistosity or differentiated crenulation cleavage with widely spaced thin M-(mica)domains separated by thick QF (quartzfeldspar)-domains (cf. Marlow and Etheridge, 1977). The $\mathrm{M}$ films are irregularly distributed in the rock and some end abruptly. The mica orientation in the $\mathrm{M}$ domains is subparallel to $\mathrm{S}_{2}$, whereas oblique or normal orientations prevail in the QF-domains (Fig. 6). In rocks with subequal amounts of quartz and mica the M domains of the differentiated crenulation cleavages are thick and irregularly distributed anastomosing domains composed of muscovite with (001) cleavage planes subparallel to $\mathrm{S}_{2}$, and minor amounts of biotite with irregularly oriented (001) cleavage planes. In mica-rich rocks kinking of mica aggregates with some local differentiation into mica-rich and quartz-rich zones is common. 

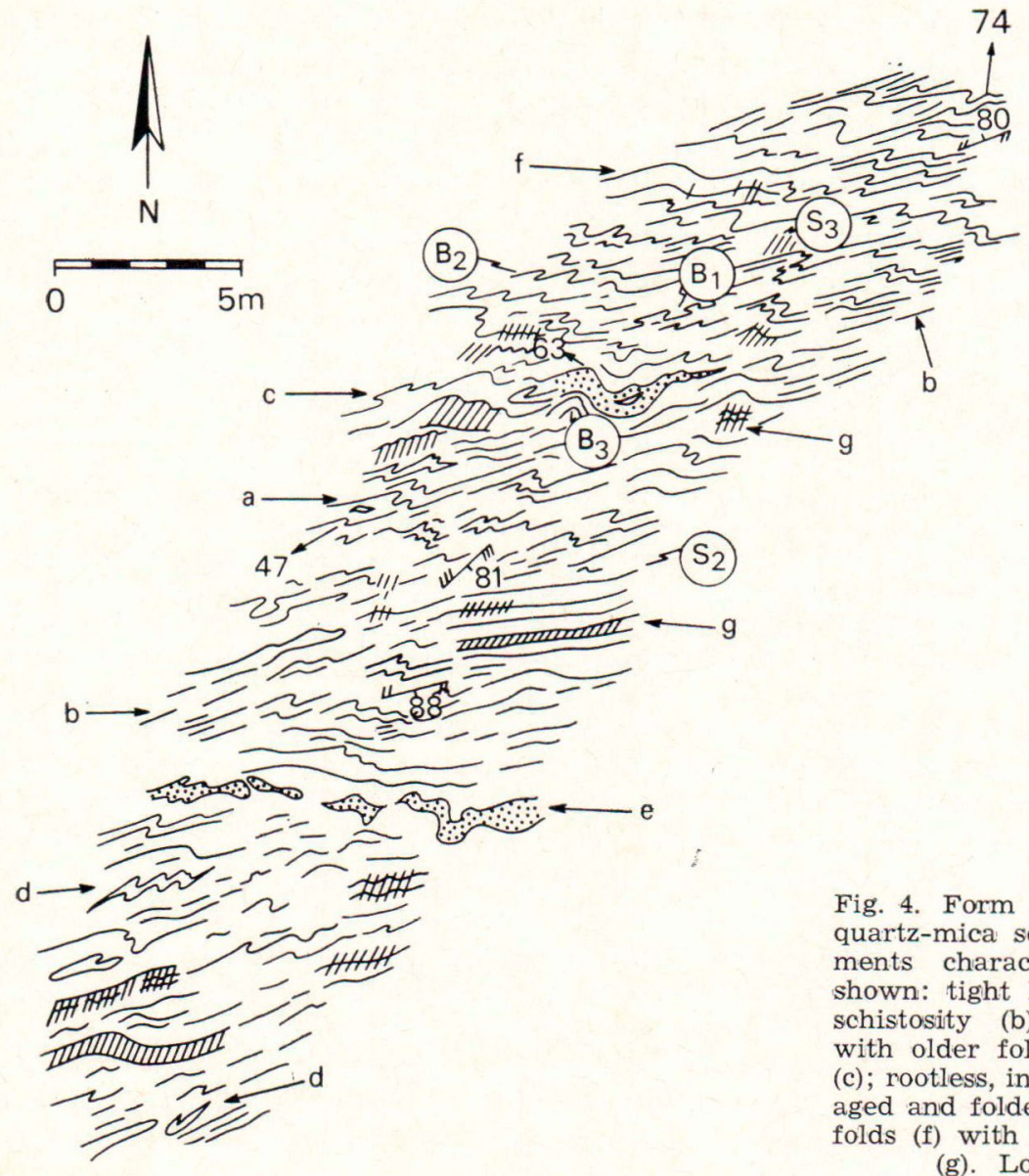

Fig. 4. Form surface map of exposure in quartz-mica schist. Several structural elements characteristic of the schists are shown: tight $\mathrm{F}_{2}$ folds (a) with penetrative schistosity (b); overprinting relationships with older folds are visible in their limbs (c); rootless, intrafolial folds (d) and boudinaged and folded gneissic layers (e); open $\mathrm{F}_{3}$ folds (f) with local $S_{3}$ crenulation cleavage (g). Location 64.99-49.78.

$\mathrm{F}_{3}$ structures

The imprint of $\mathrm{F}_{3}$ folding on the schists is localized on mesoscopic and on microscopic scale. In the field open dextral folds with wavelengths of the order of metres occur at regular intervals of $50-100 \mathrm{~m}$. In many places is the only $\mathrm{F}_{3}$ phenomenon observed crenulation cleavage, which may or may not be associated with mesoscopic folding. Fold hinges in quartz-rcih rocks are rounded, whereas micaceous rocks show kink bands and, less frequently, chevron folds.

On microscopic scale $\mathrm{F}_{3}$ deformation has formed open crenulations and local crenulation cleavage with differentiation into $\mathrm{M}$ and
QF domains (Fig. 7; cf. Marlow and Etheridge, 1977, Fig. 2). In places where $S_{2}$ is a differentiated crenulation cleavage, $S_{3}$ tends to develop as a differentiated crenulation cleavage of the same type. Where both cleavages make a small angle it is difficult to distinguish between them.

\section{$\mathrm{F}_{4}$ structures}

Open folds, kink folds, kink bands, and crenulations deforming $\mathrm{F}_{2}$ and $\mathrm{F}_{3}$ structures occur in restricted areas in the schists. Kink structures are common on thin section scale, and are restricted to thin mica films. Folds 


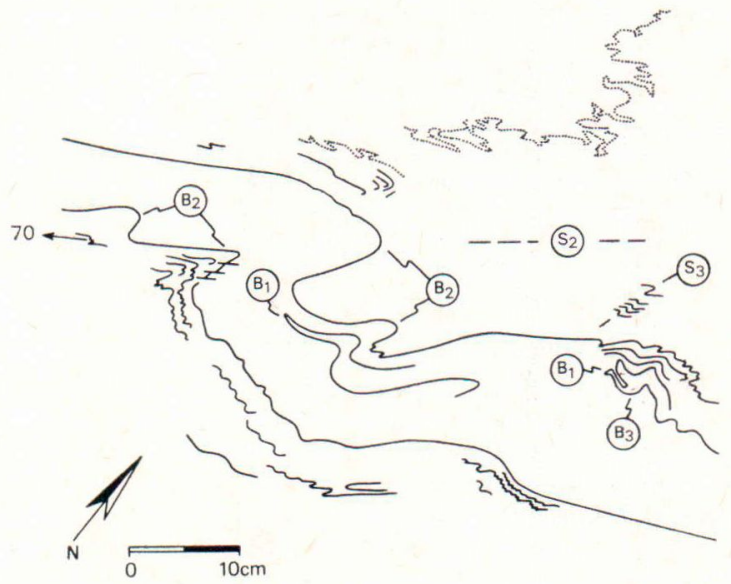

Fig. 5. Mesoscopic overprinting relationships in quartz-mica schist and folded quartz veinlets (dotted lines). Location 64.50-65.18 (E coast of Lysholmen).

and kinks seem to occur only in foliated micaceous materials striking close to northsouth. These structures have been correlated

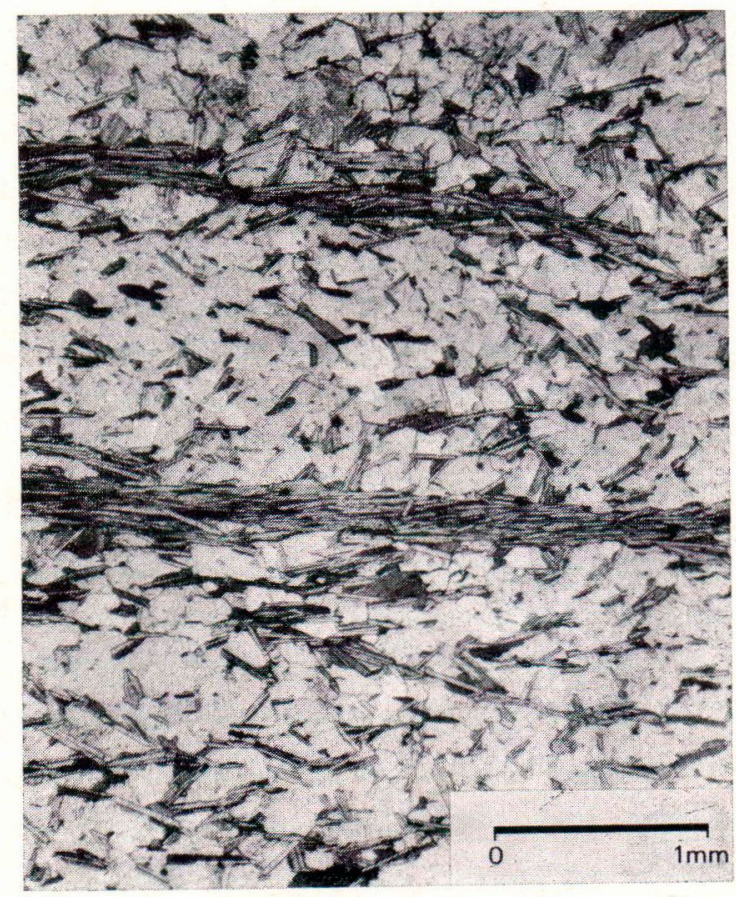

Fig. 6. $\mathrm{S}_{2}$ differentiated crenulation cleavage with quartz-rich and mica-rich domains. The crenulated $\mathrm{S}_{1}$ mica cleavage is visible in the quartzrich domains. (D522a; location 64.50-65.18, same as Figure 4). with the fourth folding phase established in the Masugnsträsk Gneisses to the north.

In vertical outcrops a horizontal crenulation lineation is observed in the $\mathrm{S}_{2}$ foliation plane. It crenulates the $\mathrm{L}_{2}$ mineral lineation, but it could not be correlated conclusively with $\mathrm{F}_{3}, \mathrm{~F}_{4}$ or any other deformation event.

\section{Masugnsträsk gneisses}

The Masugnsträsk gneisses have been divided into two structural domains: a southerly domain, (domain II in Fig. 2) characterized by a pervasive foliation that is correlated with the $\mathbf{S}_{2}$ in the Taalintehdas schists, and a northerly domain (domain III in Fig. 2) in which $F_{3}$ and $F_{4}$ folds are prominent.

Southerly domain: $\mathbf{F}_{1}-\mathbf{F}_{4}$ structures

Rootless isoclinal folds are scarce in the gneisses. In places fold-like structures, which may be $F_{1}$ or $F_{2}$, are defined by lithological contacts such as streaks and intercalations of biotite schist and boudinaged amphibolite. Layering is generally transposed parallel to $\mathrm{S}_{2}$. The $\mathrm{S}_{2}$ foliation is defined partly by irregular differentiated layering with thin $\mathrm{M}$ films separated by thick QF domains with local remnants of crenulations. More regular differentiated $\mathrm{S}_{2}$ layering with penetrative mica films has developed locally. Some outcrops exhibit a weak $\mathrm{F}_{3}$ crenulation and in very rare cases $F_{3}$ folds and an $S_{3}$ crenulation cleavage can be detected. A few $F_{4}$ kink bands may occur in such localities.

Northerly domain: $\mathrm{F}_{1}-\mathrm{F}_{3}$ structures

The northerly domain is characterized by the pronounced development of $\mathrm{F}_{3}$ and $\mathrm{F}_{4}$ structures. Generally three foliations $\left(\mathrm{S}_{2}, \mathrm{~S}_{3}\right.$, 
Fig. 7. $\mathrm{F}_{3}$ microstructures in quartz-mica schist. Mica aggregates are kinked, whereas a crenulation has developed in the quartz-rich domain. Note the serrated kinkband boundaries in the mica and the strain-free nature of both mica and quartz. Crossed nicols. (F501c; location 65.08-49.79)

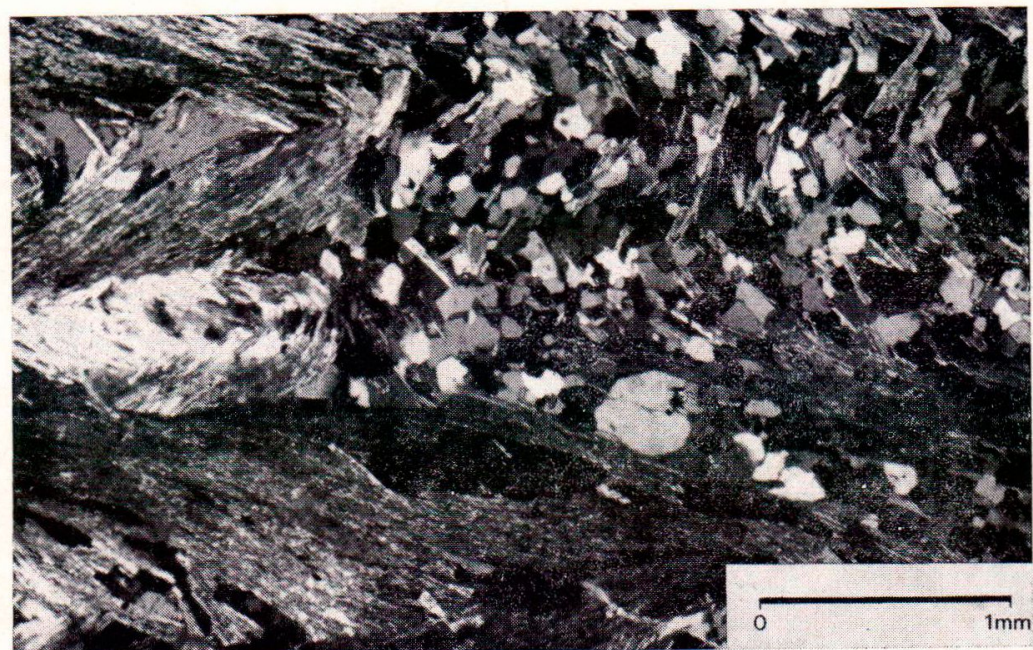

$\mathrm{S}_{4}$ ) can be observed. Notwithstanding the imprints of later deformations, $\mathrm{S}_{2}$ can be recognized on microscopic scale as somewhat differentiated, penetrative schistosity, regular biotite schistosity, differentiated layering, or foliation marked by elongate aggregates and streaks of biotite.

$\mathrm{F}_{3}$ folds are open to tight and are related to the NS trend of the foliation which occurs on a macroscopic scale to the west and northwest of the Taalintehdas area (Fig. 2). The $\mathrm{S}_{3}$ is coarse crenulation cleavage in rocks where the $S_{2}$ is of the same type. In other gneisses, differentiated schistosity is defined by biotite and some muscovite, generally with elongated streaks of biotite aggregates parallel to it. In some biotite schists the preferred orientation of biotite is exceptionally well developed (see Williams et al., 1977, Fig. $7 d)$. In areas where $F_{3}$ is well developed earlier foliations are transposed parallel to $\mathrm{S}_{3}$, and the $\mathrm{S}_{3}$ differentiated layering cannot be distinguished from the parallel $\mathrm{S}_{2}$ (Fig. 8).

Northerly domain:

$\mathrm{F}_{4}$ structures

$\mathrm{F}_{4}$ deformation features are not observed in areas with a dominant $\mathrm{S}_{2}$ (N70E) orienta- tion (Fig. 2). The $\mathrm{F}_{3}$ deformation caused reorientation of pre-existing structures and the development of a N35E trending axial plane foliation (Fig. 10). $F_{4}$ chevron folds are common in areas where the distinctly layered $S_{3}$ transposition foliation is well developed. The chevron folds generally have a sinistral vergence and their enveloping surface trends SSW. $\mathrm{S}_{4}$ differentiated layering is developed locally (Fig. 9), and well-developed crenulation cleavage is common in micaceous intercalations. $\mathrm{F}_{4}$ folds are observed to be restricted to areas where pre- $\mathrm{F}_{4}$ foliations have a roughly NS trend. It is suggested that $\mathrm{F}_{4}$ kinking and folding could take place only in those domains where the foliation was oriented roughly NS (which is in accordance with the observations in the Taalintehdas schists).

\section{Pegmatites}

Both the Taalintehdas schists and Masugnsträsk gneisses contain pegmatites parallel to the $\mathrm{S}_{2}$ transposition foliation. Boudinage and fold structures with axial plane surface parallel to $S_{2}$ are common. Penetrative axial plane foliation is not visible on mesoscopic scale in the pegmatites, although there is 

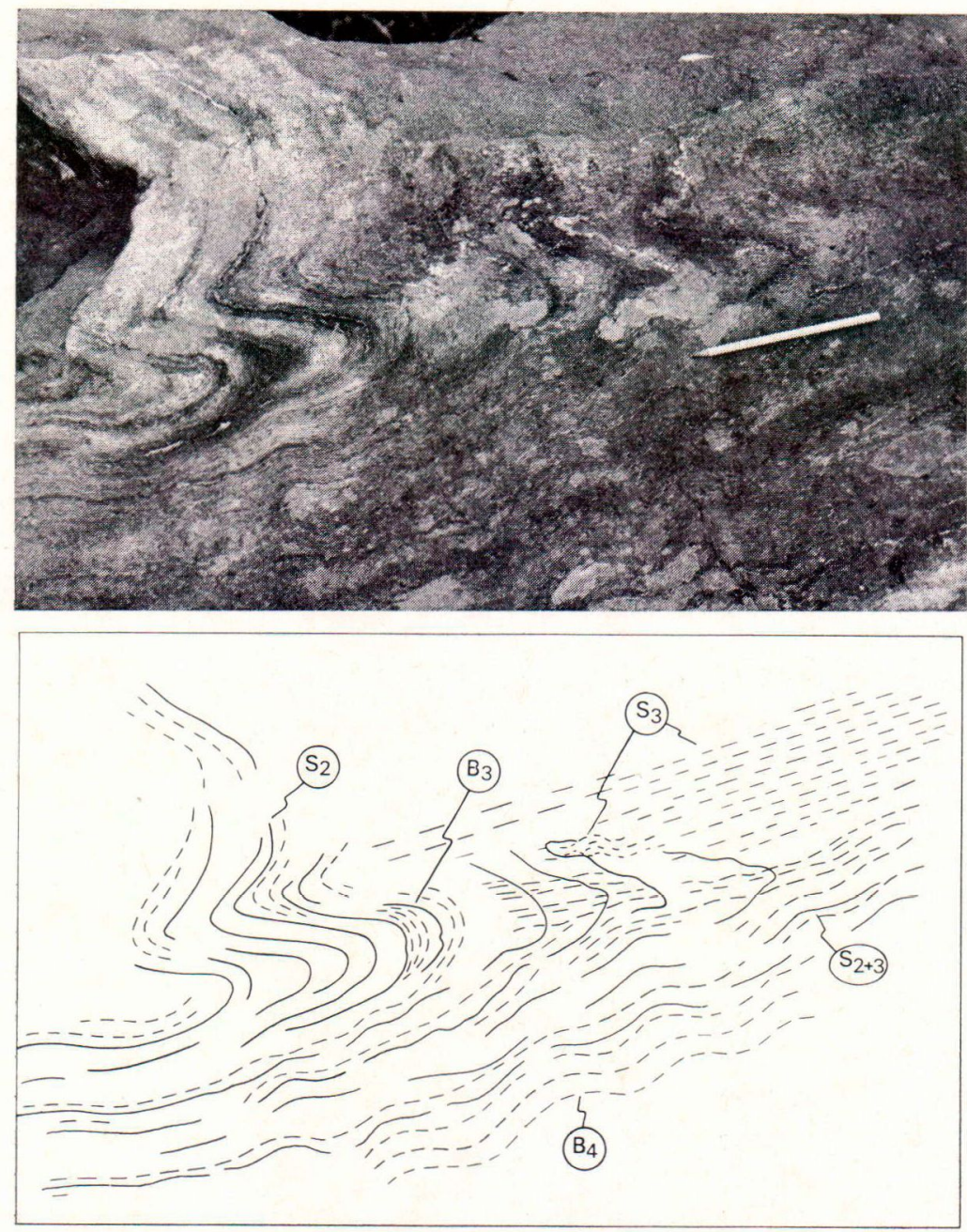

Fig. 8. $F_{3}$ fold in quartzrich gneiss. $\mathrm{S}_{3}$ differentiated layering has developed in the hinge area (top right). $\mathrm{S}_{2}$ and $\mathrm{S}_{3}$ cannot be distinguished in the limbs. Open $\mathrm{F}_{4}$ crenulations overprint the $\mathrm{F}_{3}$ fold. Location 66.04 49.00 . some local fracturing parallel to $\mathrm{S}_{2}$. Other pegmatite bodies cross-cut $\mathrm{F}_{3}$ fold structures, but no relationship with $\mathrm{F}_{4}$ structures could be established. Thus a distinction is drawn between pre- $\mathrm{F}_{2}$ and post- $\mathrm{F}_{3}$ pegmatites.

\section{Macroscopic interpretation}

Figure 2 is a structural compilation of the Taalintehdas area. The macroscopic structure cen be interpreted in terms of the fold generations distinguished on mesoscopic scale. A dominant transposition foliation, $\mathrm{S}_{2}$, is refolded by a macroscopic fold with a N35E trending axial surface. The large scale folding is matched by the vergence of the $\mathrm{F}_{3}$ mesoscopic folds. An $\mathrm{S}_{3}$ transposition foliation is locally developed in the hinge area of the macroscopic fold as outlined by the large quartzite body. $\mathrm{F}_{4}$ chevron folds are locally developed in restricted areas and domains of various sizes, characterized by a roughly NS orientation of pre- $\mathrm{F}_{4}$ foliations.

\section{Deformation and metamorphism}

The present microstructure of a rock is the end product of many processes operating 

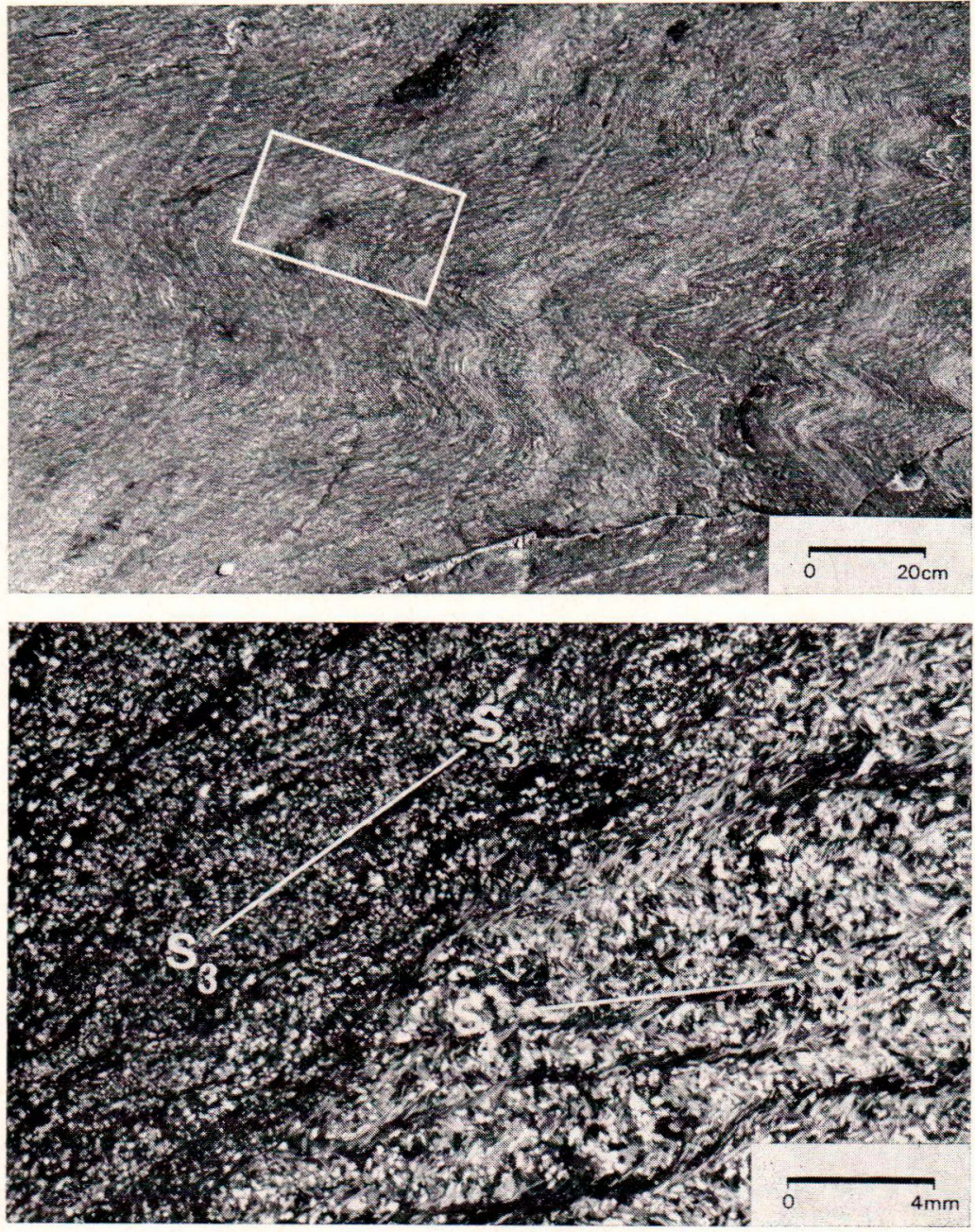

Fig. 9 a. $\mathrm{F}_{4}$ chevron folds with incipient development of $\mathrm{S}_{4}$ differentiated layering in quartz-rich gneisses. Outlined area may be compared with Figure $9 \mathrm{~b}$. SW running lineations are glacial striations. Location $65.95-49.09$. during geological history. To assess the imprint of any of these processes on microstructure development, a careful chronological analysis of the relationship between deformation and metamorphism is necessary (Vernon, $1977 \mathrm{~b}$ ). An attempt to identify realistic metamorphic reactions is desirable (Vernon, 1976).

The predominant microstructures in the schists and gneisses, described above, are differentiated crenulation cleavages or differentiated layerings with quartz-feldspar and mica domains. It is important to know when recrystallization and growth processes operated in the various minerals and when stable metamorphic microstructures could have formed. In the following the microstructures of the individual minerals are described and an attempt is made to correlate the microstructural development of these minerals with the development of the successive foliations.

Quartz occurring with feldspar forms a finegrained (ca. $0.1 \mathrm{~mm}$ ), granoblastic matrix. The individual grains have a straight or slightly undulatory extinction. Grain boundaries are slightly curved and generally meet in triple points. A polygonal mosaic ('foam') microstructure is locally present. The grain size varies with the number and size of inclusions, such as mica, dispersed in the rock. Patches and veins of coanse-grained (up 

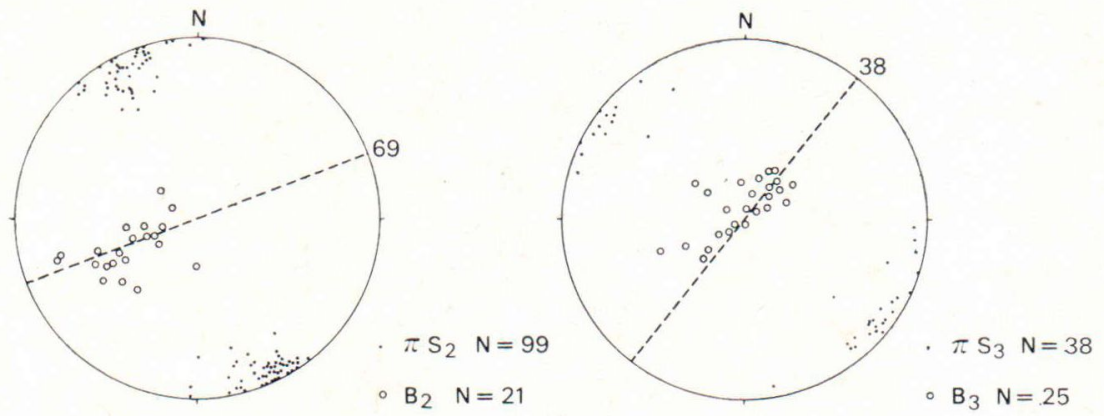

DOMAIN ।

Taalintehdas

Schists
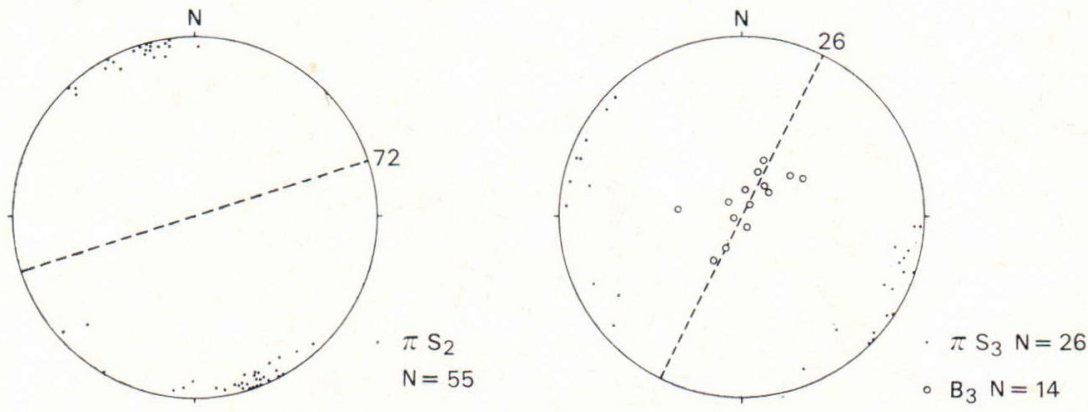

DOMAIN II

Southerly

Masugnsträsk

Gneisses
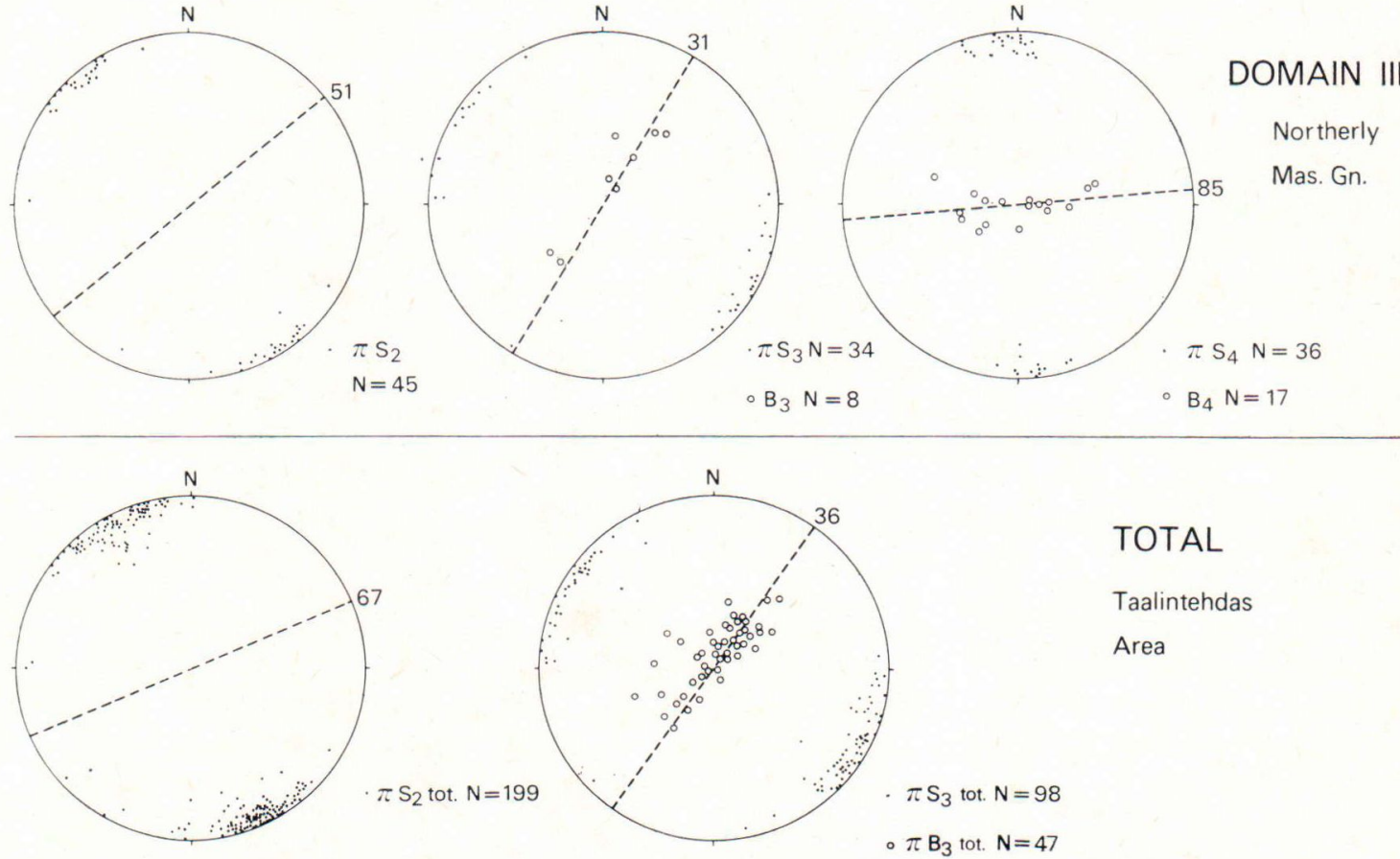

TOTAL

Taalintehdas

Area

Fig. 10. Stereograms of the Taalintehdas are corresponding to the domains of Figure 2. 
to $1.5 \mathrm{~mm}$ ) quartz occur where inclusions are rare. These observations may be interpreted as growth (grain boundary migration) and grain adjustment features where the migration of grain boundaries was controlled by the presence of inclusions. Exaggerated grain growth (Vernon, 1976) may be involved in the origin of the coarser grained patches. Growth adjustment fabrics are present in all $F_{1}$ to $\mathrm{F}_{4}$ microstructures of both schists and gneisses. Thus, in the Taalintehdas schists the polygonal quantz fabrics have developed at least until after $\mathrm{F}_{3}$. Intragranular deformation (undulatory extinction, deformation bands) has been been observed in the vicinity of some $F_{A}$ kinked micas. This suggests that recrystallization and grain growth of quartz could not operate there effectively during or after $\mathrm{F}_{4}$. In the Masugnsträsk gneisses, however, where strain-free and grain boundary adjusted polygonal quartz fabrics are present in the folded rocks (Fig. $9 \mathrm{~b}$ ), it is clear that growth and grain boundary adjustment of quartz took place at least until during or after $\mathrm{F}_{4}$.

Feldspars, if present, are part of the quartzrich granoblastic matrix. Microcline in the Masugnsträsk gneisses has a polygonal fabric in the matrix as well as in microcline aggregates. In it suggested that grain boundary adjustment took place until during or after $\mathrm{F}_{4}$.

Biotite and muscovite show similar structures, but with some morphological differences. Muscovites commonly have larger length to width ratios, and the biotites in a muscoviterich environment are truncated by (001) boundaries of the surrounding muscovites (Fig. 11). Biotite tends to grow in certain areas, such as the strain shadows of large porphyroblasts. In some $\mathrm{F}_{3}-$ or $\mathrm{F}_{4}$-kinked muscovite aggregates the muscovite has an undulatory character due to slight bending. If the bending is sharper, serrated kink band boundaries are present (Figs. 7 and 11). In general both muscovite and biotite are more or less strain free and have developed rational impingement boundaries, with (001) of muscovite dominating over rational biotite boundaries (Fig. 11). This means that the present microstructure is a result of growth and grain boundary energy reducing processes (Etheridge and Hobbs, 1974; Vernon, 1977a; Williams et al., 1977) which appear to have operated late in history (until during or after $\mathrm{F}_{4}$ ).

The microstructures of quartz, feldspar and mica as described above, strongly suggest that a late modification of the microstructure of the quartz-mica matrix is possible. Hence microstructural observations on these minerals cannot be associated unambiguously with the deformation history established (see discussion). It is possible, however, to study the relationships of critical metamorphic minerals to $\mathrm{F}_{1}$ to $\mathrm{F}_{4}$ microstructures (foliations, folds).

Cordierite forms elongated porphyroblasts which are generally parallel to $S_{2}$, or parallel to $S_{1}$ in the more open $\mathrm{S}_{2}$ crenulation cleavages. Relations between internal $\left(\mathrm{S}_{\mathrm{i}}\right)$ and external $\left(\mathrm{S}_{\mathrm{e}}\right)$ foliations are difficult to interpret since many of the blasts have been pseudomorphed by alteration minerals that obliterate earlier intragranular structures and may even have influenced inclusion fabrics. However, the presence of straight inclusion patterns in some blasts suggests post- $F_{1}$ (pre- $F_{\odot}$ ?) growth of cordierite. Some grains have been folded during $\mathrm{F}_{3}$ deformation (Fig. 12), and many others show evidence of a rather rigid behaviour such as intragranular cracks parallel to $\mathrm{S}_{3}$, rotation of elongated blasts parallel to $\mathrm{S}_{3}$, and the growth of biotite in their strain shadows. The porphyroblasts are therefore pre- $\mathrm{F}_{3}$.
Fig. 11. $F_{3}$ kink in mica aggregate from Taalintehdas schist. Individual micas are strain free and have grown out to impingement. Note the dominance of muscovite (001) over biotite (001) boundaries.

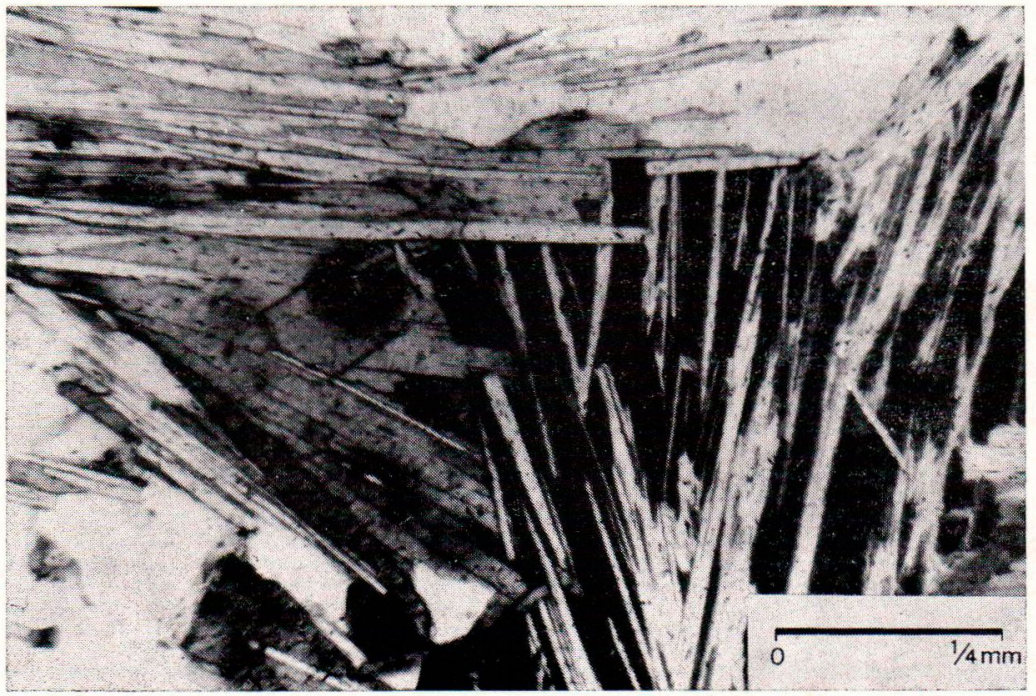




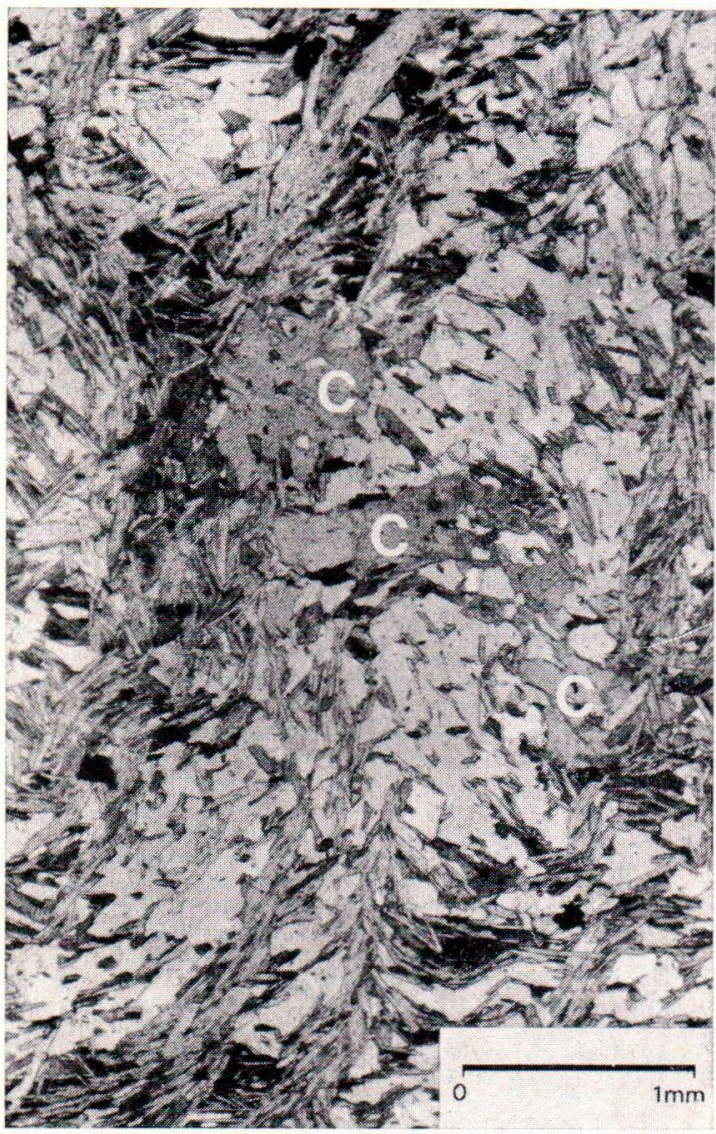

Fig. 12. $\mathrm{F}_{3}$ crenulated cordierites in quartz-mica schist (Sample F501b; location 65.08-49.79)

A few porphyroblasts show a similar relation with respect to $\mathrm{F}_{2}$ structures. Hence the orientation of many elongated blasts parallel to $\mathrm{S}_{2}$ may be the result of transposition during $F_{2}$. Nucleation and growth of cordierite can thus be interpreted as pre- or early syn-F2 (Fig. 14).

Fibrolitic sillimanite is present as intergrowths with biotite or quartz, or both, and lack any optical evidence of deformation. Biotite and quartz have a reduced grain size and ragged grain boundaries where sillimanite needles are enclosed. Fibrolite needles pass without deflection of trails from one quartz or biatite grain into another of different orientation. This indicates that fibrolite was present before growth and/or grain boundary adjustment of quartz and biotite took place (Vernon and Flood, 1977). The fibrolite was folded during $F_{2}$ deformation (Fig. 13) and is thus earlier than part of the $\mathrm{F}_{2}$ deformation at least.

Andalusite porphyroblasts are prekinematic to at least part of the $\mathrm{F}_{3}$ deformation as a rigid behaviour similar to that of cordierite is observed. The curved inclusion fabric, continuous with the external $\mathbf{S}_{2}$ foliation, that is occasionally present suggests synkinematic growth with respect to $\mathrm{F}_{\mathrm{g}}$. Comparison of fine-grained mica inclusion patterns with coarser-grained external mica fabrics is ambiguous, it being possible to explain the growth as both synkinematic and postkinematic with respect to $\mathrm{F}_{2}$.

Garnet porphyroblasts have developed in bioitite-rich parts of the Masugnisträsk gneisses. Inclusion fabrics defined by rutile, ilmenite, and sphene show a well-developed $\mathrm{S}_{2}$ crenulation cleavage in the core of some blasts. Opaque minerals in the rim of these garnets are aligned parallel to and continuous with the external $S_{3}$ schistosity. Garnet porphyroblasts in a biotiterich layer in the Taalintehdas schists have a straight inclusion (quartz, ilmenite, rutile) fabric in the core, which becomes curved towards the edge. It is continuous with the external $\mathbf{S}_{2}$ schistosity, which was crenulated during $\mathrm{F}_{3}$ deformation. Many garnets with an elongated habit have been rotated parallel to $\mathrm{S}_{3}$ and thus their straight inclusion fabric is discontinuous with the external foliation. These observations suggest that garnet growth started during or after the $\mathrm{F}_{2}$ deformation and was contemporaneous with at least part of the $\mathrm{F}_{3}$ deformation.

Clino-amphibole porphyroblasts with straight quartz inclusion patterns are generally aligned with their c-axes parallel to $\mathrm{S}_{2}$ surfaces. They are deformed by $\mathrm{F}_{3}$ and show undulatory extinction; subgrains and recrystallization have developed locally. Coarse porphyroblasts are surrounded by small recrystallized amphiboles (cf. Bierman, 1977). It is difficult to set time limits to the amphibole growth; nevertheless, it appears to have started before the second deformation phase, whereas recrystallization occurred during the third phase.

Some events younger than the fold generations described above have been recorded in both the Taalintehdas schists and the Masungsträsk gneisses. Their relative age is based cross-cutting relationships observed in thin section. First, small-scale fracturing and mylonitization have created thin zones (ca. $0.2 \mathrm{~mm}$ ) with an aphanitic matrix, surrounded by strongly kinked, fish-shaped micas and deformed quartz grains that show recrystallization along deformation bands. Quartz grains without any apparent deformation feature, however, occur adjacent to the mylonite suggesting either strongly heterogeneous deformation or recrystallization during or after mylonitization. Strongly kinked mica without any evidence of recovery occurs throughout the area and is considered to be related to this late fracturing. 
Fig. 13. $\mathrm{F}_{2}$ folded fibrolitic sillimanite intergrown with biotite. (Sample F551; location $65.00-49.78)$

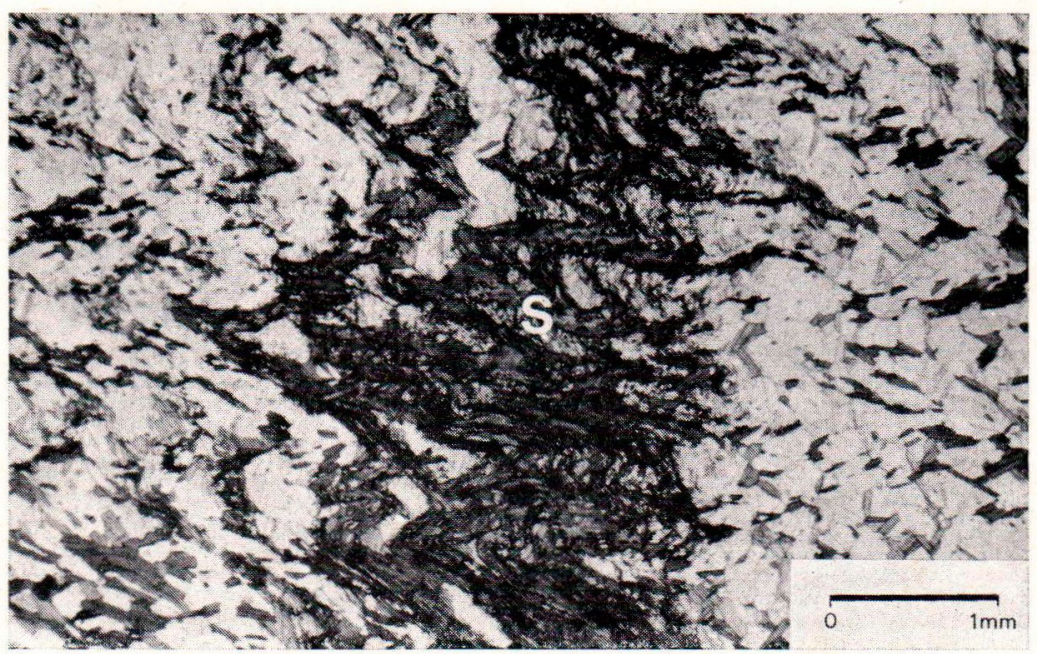

Thin microcline veinlets $(0.1-1 \mathrm{~mm}$ wide) have formed along irregular cracks crosscutting all the previously described structures. They are generally normal to $S_{2}$ surfaces.

Finally, some pyrite veinlets $(0.1-0.3 \mathrm{~mm}$ wide), partially or completely altered into iron-hydroxides, have formed along matured polygonal matrix grain boundaries and foliations.

\section{Discussion}

In interpreting the microstructures of the schists and gneisses, it is important to note the following: (1) Differentiated layerings are dominant fabric elements in both schists and gneisses. Transition from crenulations via crenulation cleavages to differentiated layerings can generally be traced. (2) The matrix minerals (quartz, feldspar, mica) are optically clear and bear hardly any evidence of intracrystalline deformation. Local kinking of micas, undulatory extinction, deformation bands and subgrain development in quartz can be related to late stage (post folding) shearing and fracturing of the rocks. Grain boundary migration and grain bound- ary adjustment of quartz and micas has been demonstrated to continue until after the fourth fold generation.

A detailed analysis of the development of a layered crenulation cleavage by Marlow and Etheridge (1977) similar to the analyses described in the present paper showed that chemical, mineralogical, grain size, and preferred orientation changes are involved. These authors suggest that processes of the 'diffusive mass-transfer' type play a major role in the development of differentiated layering. A major argument in favour of this theory is the absence of phenomena indicative of intracrystalline deformation. If intracrystalline dislocation flow mechanisms (cf. Nicholas and Poirier, 1976) should have been dominant, extensive annealing recrystallization would have been required to remove all evidence of intracrystalline deformation.

The development of a polygonal foam microstructure in microcline in the schists and gneisses around Taalintehdas can be explained if the development of differentiated layering involved dominant diffuse masstransfer processes. In rocks where quartz is deforming by intracrystalline plasticity, microcline is generally known to exhibit brittle behaviour (e.g. Bossière and Vauchez, 1978; 


\begin{tabular}{|c|c|c|c|c|c|}
\hline MINERALS & $F_{1}$ & $F_{2}$ & $F_{3}$ & $\mathrm{~F}_{4}$ & $\begin{array}{l}\begin{array}{l}\text { Fractu- } \\
\text { ring }\end{array} \\
\end{array}$ \\
\hline QUARTZ & & & & & \\
\hline FELDSPARS & & & & & \\
\hline MICAS & & & & & \\
\hline CORDIERITE & & & & & \\
\hline SILLIMANITE & & & & & \\
\hline ANDALUSITE & & & & & \\
\hline GARNET & & & & & \\
\hline $\begin{array}{l}\text { CLINO- } \\
\text { AMPHIBOLE }\end{array}$ & & & & & \\
\hline
\end{tabular}

Fig. 14. Schematic diagram illustrating the relationship of deformation and metamorphism as inferred from microstructures. Quantz, feldspar and mica have recrystallized during each deformation phase. Microcline veinlets have developed after the fracturing period. The highest probability of nucleation and growth is estimated at places where fish are thickest. Clinoamphibole recrystallized during $\mathrm{F}_{3}$.

Lister and Price, 1978). Since both quartz and microcline develop foam microstructures, a deformation regime not dominated by intracrystalline dislocation flow in quartz alone is indicated. Diffusive mass-transfer processes seem to be required for microcline to develop a foam microstructure.

The development of differentiated layering during each of the four folding events places constraints on the interpretation of fabrics of structures older than $\mathrm{F}_{4}$. Growth and grain boundary adjustment during $\mathrm{F}_{4}$ deformation may have affected some and perhaps all of the features characteristic of deformation during earlier phases $\left(\mathrm{F}_{1}, \mathrm{~F}_{2}, \mathrm{~F}_{3}\right)$.

In summary, if we assume that intracrystalline plasticity was important during a large part of the deformation history, annealing recrystallization must have played a key role too, at least during and/or after the last deformation phase, because of the presence of growth and grain boundary adjusted fabrics in $\mathrm{F}_{4}$ deformed rocks. It seems inevitable that the pre-existing $\mathrm{F}_{1}, \mathrm{~F}_{2}$, and $\mathrm{F}_{3}$ structures should have been affected. If, on the other hand, we assume that processes of diffusive mass-transfer were dominant, then only growth and grain boundary adjusted fabrics would have developed (cf. Marlow and Etheridge, 1977) and the influence on the fabric of older structures is more difficult to assess from microstructural observation.

The present paper shows that critical metamorphic minerals grew at different stages of the metamorphic and structural history (Fig. 14). Since differentiation processes took place during each deformation phase, quartz, feldspars and micas are inferred to have recrystallized during successive deformation events. In multiple deformed and differentiated metapelites matrix minerals have a good chance of reequilibration during recrystallization. This holds not only for the rocks described above but also for metapelites from other parts of Kemiö Island (and any other comparable area) where only one (transposition) foliation is dominant. Studies on element partitioning between coexisting miner- 
als should provide information on the possible loss of chemical equilibrium in recrystallized matrix minerals, e.g. in biotite-garnet and biotite-cordierite relationships.

\section{Regional interpretation}

The structural history established in the Taalintehdas area offers a basis upon which to interpret of the surrounding areas. To test the applicability of the Taalintehdas structure to adjacent areas, a number of localities were selected on Kemiö Island. The location of these areas is marked in Figure 1. The data obtained at these localities are based on field observations only; the analysis of microscopic structures has yet to be done.

In many of the localities where structural analysis has been carried out a similar succession of four fold generations has been established. As $\mathrm{S}_{2}$ transposition foliation is the dominant foliation in the Taalintehdas area, it is inferred that the dominant foliation, which has a similar orientation in adjacent parts of Kemiö Island, is also related to $F_{2}$. This is affirmed at most of the localities investigated.

As described in the section on geological setting, north-south trending foliations prevail west of Taalintehdas. Structural analysis in this area shows that local $\mathrm{F}_{3}$ folding reoriented older foliations into a north-south direction. Additional $\mathrm{F}_{4}$ deformation is locally present. The dome structure around Bergö is formed by the overprinting of a fourth generation structure over older ones (P. F. Williams, C. R. van Staal, pers. comm.). A sequence of metamorphic gabbros, pillow basalts and agglomerates near Vestlax shows four generations of folds, which have been correlated with $\mathrm{F}_{1}$ to $\mathrm{F}_{4}$ structures at Taalintehdas (J. H. M. Coenen, pers. comm.). Gabbroic amphibolites on Kemiö Island occur in at least two distinctly different geological settings. The majority of the amphibolites are intercalated in the supracrustal gneiss series as massive bodies transected by local shear zones. A metagabbro body and the surrounding supracrustal rocks just NW of the Taalintehdas area were investigated in detail. The supracrustal gneisses show a sequence of $\mathrm{F}_{1}, \mathrm{~F}_{2}$ and $\mathrm{F}_{3}$ folds which have been correlated to folds defined by the contact of both rock units and by shear zones inside the gabbro body (Verhoef, 1977). The body north of Pederså shows overprinting of large scale $\mathrm{F}_{1}$ and $F_{2}$ folds (Verhoef, op.cit.). These observations suggest that these magmas were emplaced before the first deformation phase.

Microstructures in rocks from the 'synkinematic' rock suite are more difficult to date. The gabbroic rocks show a penetrative amphibole lineation and evidence of local $\mathrm{S}_{2}$ shear zones parallel to it (Dietvorst, 1977). The tonalitic and granodioritic rocks have a penetrative $\mathrm{E}-\mathrm{W}$ foliation that continue into the surrounding supracrustal rocks (Simonen, 1960) and into the shear zones in the metagabbros (Dietvorst, op.cit.). $\mathrm{F}_{1}-\mathrm{F}_{2}-\mathrm{F}_{3}$ overprinting may be present at a locality in migmatitic tonalite north of the gabbros in the northwest of Kemiö Island. It is generally very difficult to establish the existence of $\mathrm{F}_{1}$ deformation structures in the synkinematic intrusives.

Our preliminary findings can be summarized as follows. The supracrustal rock series, including the intercalated metagabbros, have undergone at least four folding events, with $\mathrm{F}_{2}$ structures dominant at most places. The 'synkinematic' tonalite suite is of a pre- $\mathrm{F}_{2}$ age. The $\mathrm{F}_{2}$ deformation is characterized by extensive transposition of earlier foliations and rock bodies parallel to the $\mathbf{S}_{2}$ axial plane schistosity. This explains the simple EW pattern of foliations on a macroscopic scale (Fig. 1). $F_{3}$ deformation is only locally developed and in the southern part of Kemiö Island $\mathrm{F}_{4}$ structures have a dominating 
influence on the macrostructural pattern visible on the map. If $\mathrm{F}_{3}$ is responsible for pre- $\mathrm{F}_{4}$ variation in $\mathrm{S}_{2}$ (as in the Taalintehdas area), then $\mathrm{F}_{3}$ by orientating $\mathrm{S}_{2}$ favourably localizes $\mathrm{F}_{4}$.

Acknowledgements - Thanks are due to Prof. Dr. H. J. Zwart for his assistence in the selection of the area, and Dr. P. F. Williams for his stimulating guidance through all stages of the work.
Drs. Paul Williams, Rob Knipe, Piet Maaskant and László Westra critically reviewed concepts of the paper. Special thanks are due to Mr. and Mrs. Johansson from Nivelax, Finland, for their friendship and hospitality during the field work. The drawings were prepared by Mr. J. J. J. Bergenhenegouwen and the photographs by Mr. W. C. Laurrijssen, both of Leiden University. One of the authors (E.J.L.D.) acknowledges The Netherlands Organization for the Advancement of Pure Research (Z.W.O.) for financial support.

\section{References}

Bierman, C. (1977) The formation of sheaf-like aggregates of hornblende in garbenschiefer from the Central Scandinavian Caledonides. Tectonophysics, 39, 487-499.

Bossière, C. and Vauchez, A. (1978) Déformation naturelle par cisaillement ductile d'une granite de Grande Kabylie Occidentale (Algérie). Tectonophysics, 51, 57-81.

Dietvorst, E. J. L. (1977) Structural analysis of some key areas on Kemiö Island. Manuscr. Free Univ., Amsterdam. 62 pp.

Eskola, P. (1914) On the petrology of the Orijärvi Region in southwestern Finland. Bull. Comm. géol. Finlande, 40, 277 pp.

Etheridge, M. A. and Hobbs, B. E. (1974) Chemical and deformational controls on recrystallization of mica. Contrib. Mineral. Petrol., 43, 111124.

Hobbs, B. E., Means, W. D. and Williams, P. F. (1976) An outline of structural geology. John Wiley \& Sons, Inc., New York.

Lister, G. S. and Price, G. P. (1978) Fabric development in a quartz-feldspar mylonite. Tectonophysics, 49, 37-78.

Marlow, P. C. and Etheridge, M. A. (1977) The development of a layered crenulation cleavage in mica schists of the Kanmantoo Group near Macclesfield, South Australia. Geol. Soc. Am. Bull., 88, 873-882.

Nicholas, A. and Poirier, J. P. (1976) Crystalline plasticity and solid state flow in metamorphic rocks. John Wiley \& Sons, Inc., New York.

Simonen, A. (1960) Plutonic rocks of the Svecofennides in Finland. Bull. Comm. géol. Finlande, 189, $101 \mathrm{pp}$.

- (1971) Das finnische Grundgebirge. Geol. Rundschau, 60, 1406-1421.

Verhoef, P. N. W. (1977) Structural analysis of the Dalsbruk (Taalintehdas) area. Manuscr. Free Univ., Amsterdam. 88 pp.

Vernon, R. H. (1976) Metamorphic processes. Reactions and microstructure development. George Allen \& Unwin Ltd., London.

- (1977 a) Microfabric of mica aggregates in partly recrystallized biotite. Contrib. Mineral. Petrol., 61, 175-185.

- (1977 b) Relations between microstructures and metamorphic assemblages. Tectonophysics, 39, 439-452.

- and Flood, R. H. (1977) Interpretation of metamorphic assemblages containing fibrolitic sillimanite. Contrib. Mineral. Petrol. 59, 227235.

Williams, P. F., Means W. D. and Hobbs, B. E. (1977) Development of axial-plane schistosity in experimental and natural materials. Tectonophysics, 42, 139-158.

Manuscript received, July 15, 1979 